\title{
Sedimentological, Lithostratigraphic, Clayey and Exoscopic Study of the Senonian Series of District Imini, Asfalou and Anmitar, Central High Atlas, Morocco
}

\author{
Abdelouhed Farah ${ }^{1} 8(\mathrm{D}) 凶$, Ahmed Algouti ${ }^{2}$ (D), Abdellah Algouti ${ }^{3}$ 8(D), Abdelhalim Tabit ${ }^{4}$ (D) \\ Hadach Fatiha ${ }^{5} \mathrm{O}$ (D) and Zahra Mourabit 6 8 (D) \\ ${ }^{123456}$ University of Cadi Ayyad, Faculty of Sciences Semlalia, Department of Geology, Geoscience Geotourism Natural Hazards \\ and Remote Sensing Laboratory (2 GRNT), BP 2390, 40000, Marrakech, Morocco
}

$\triangle$ Corresponding Author: Abdelouhed Farah, E-mail: farah6faragh@gmail.com

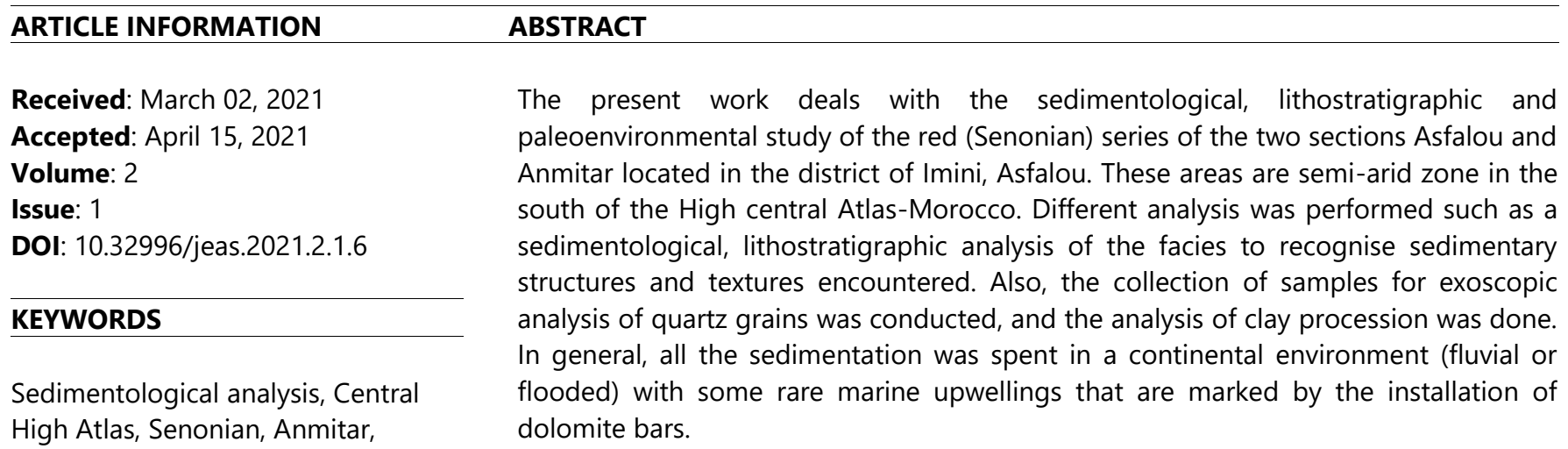

Asfalou

\section{Introduction}

The Moroccan High Atlas is an orogenic system considered to be the result of the recent Cenozoic evolutionary tectonic inversion of the Triassic and Jurassic rift systems (Frizon et al.,2008). It presents the result of a long and complex tectonosedimentary evolution linked to the Mesozoic continental rifting evolution of Pangaea, the subsequent opening of the Atlantic and northwestern Tethys Oceans (pre-orogenic period (Giese et al.,1992; Laville,1992; Mattauer et al.,1977), and subsequently, the Cenozoic convergence between Africa and the European plates that led to a complete tectonic inversion of the striated basins orogenic period (Frizon et al., 2008; Mattauer et al.,1977). The North Atlas fault delimits the WSW-ENE trend chain to the north and the South Atlas fault to the south, which is called the master faults of the striated basins active during the preorogenic period and then hosting inversions during the orogenic period (Frizon et al, 2009). This intracontinental inversion chain is subdivided into three zones: The Western High Atlas, the Eastern High Atlas and the Central High Atlas (Figure.1), which is the field of study of this work. Specifically, the present study includes the districts of Imini, Asfalou, and Telouet; which are semi-arid zone in the south of the Central High Atlas.

\section{K C AL-KINDI CENTER R D FOR RESEARCH AND DEVELOPMENT} Your gateway to world-class research

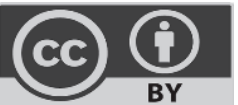

Published by Al-Kindi Center for Research and Development, London, United Kingdom. Copyright (c) the author(s). This open access article is distributed under a Creative Commons Attribution (CC-BY) 4.0 license 

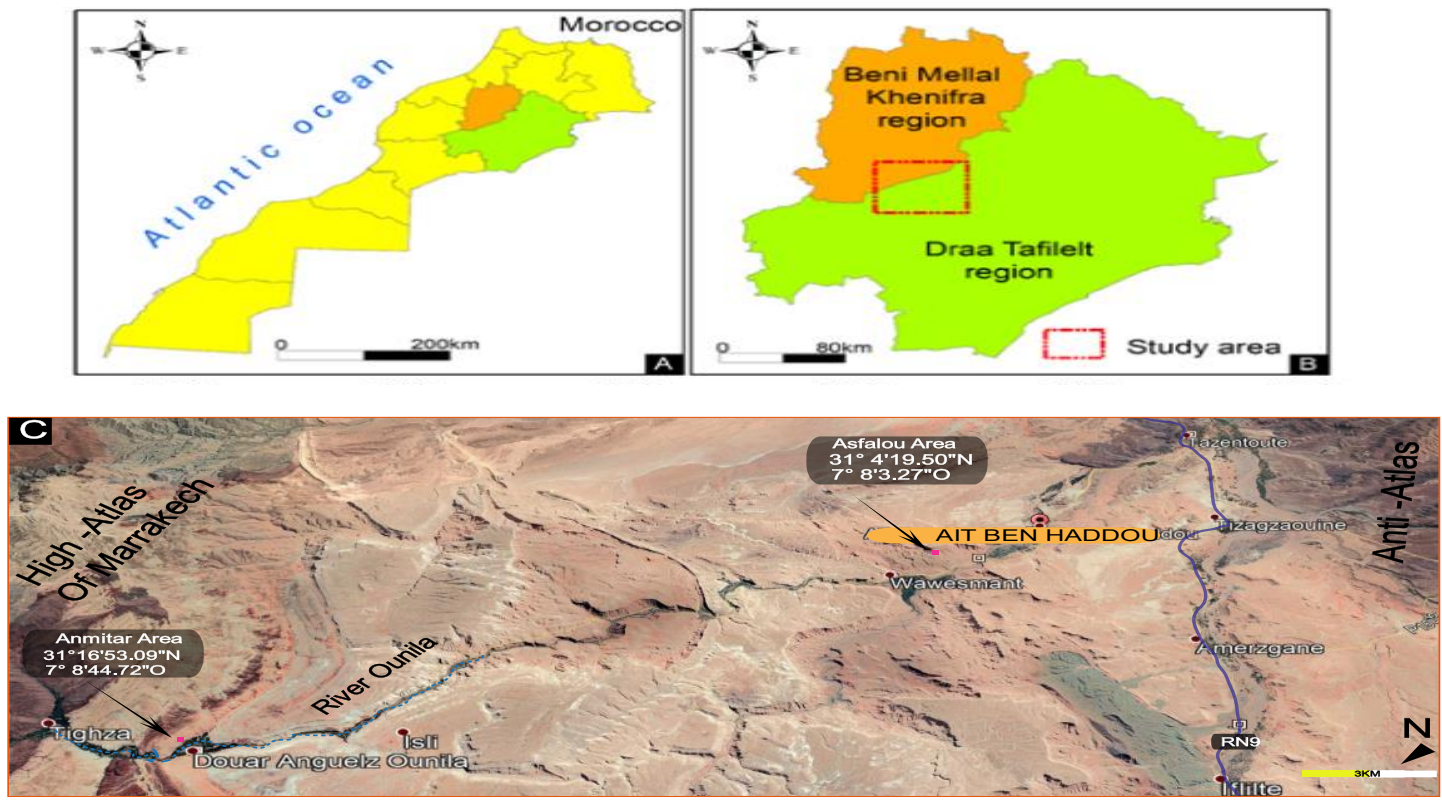

Figure. 1 Location of the study area: (A) Morocco, (B) The provinces of the Draa Tafilalet region, and (C) Google Earth image of the study area.

\section{Geological setting}

In the present study area, the adjacent massifs contain igneous (mainly granite) and metamorphic rocks of pre-Triassic age that were deformed during the previous orogenesis. They are unconformably overlain by Cenozoic sedimentary rocks deposited in various sedimentary environments (Ettaki et al.,2008). The region has undergone only slight west-to-east buckling. Reverse faults materialize the brittle accidents affecting the cover with the following main directions: WNW-ESE (Bouazzer and Assaoud faults) and WSW-ENE (Bulgir, Tighermit and Timkit faults). Sometimes, there are abrupt folds (Pouit, 1964). (Figure. 2).

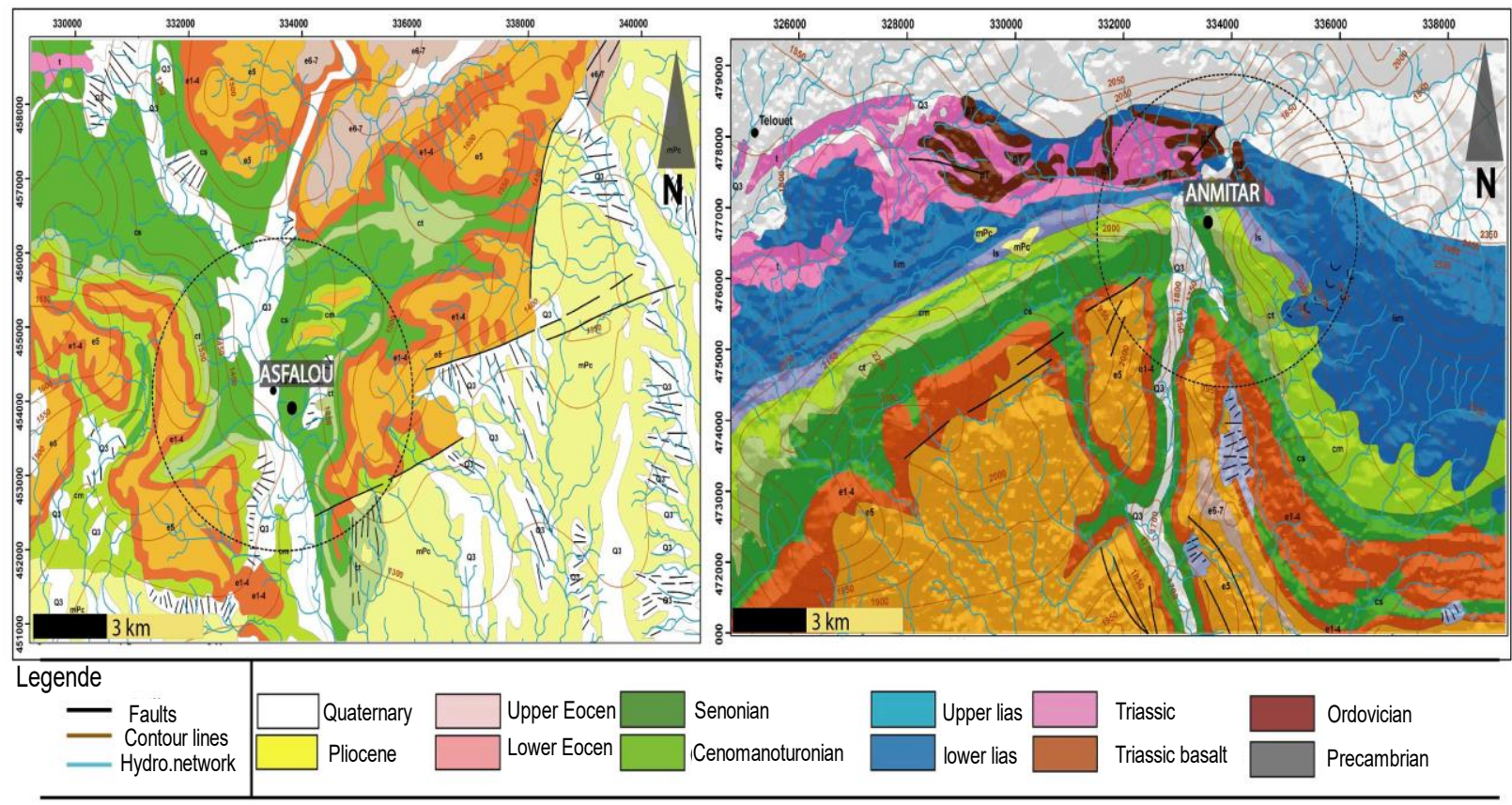

Figure.2 Lithostructural map extracted from the geological map of Ouarzazate Alougoum at (1/100000), on the right Anmitar region, on the left Asfalou region 


\section{Methodology}

Two sections were surveyed and sampled bench by the bench in the basin locality of Asfalou and Anmitar. These field surveys followed one another vertically, with few gaps invisibility. In the absence of stratigraphic markers, the sedimentological analysis of facies to de-complete the depositional media was carried out. On the one hand, in the field by recognising sedimentary structures and textures and. On the other hand, the study of samples in macroscopy (polished surfaces) and exoscopic analysis for the quartz grains was done by systematic prospecting of the relief of the grains (Quartz in the case studied), aiming at the identification of the phenomenorphic characters and their localization. (PhM= Phenomenorphic) (Marcelino et al.,1999). A PhM is made up of all characters that will appear on the surface of the grain after the formation of the mother rock: at the place of origin, during transport, during the immobilization phases and finally during deposition. The clayey side in these reddish formations of the upper Cretaceous because the evolution of the clayey and non-clayey assemblages in this Central High Atlas Basin will depend mainly on the conjugation of tectonic (subsidence and halocinesis), eustatic and climatic and other influences. The analysis of these factors may soon determine the environments of the clay deposits of these reddish formations.

\section{Result and discussion} 4.1 Stratigraphy

The sedimentary series of the Mesozoic to Cenozoic southern plateaus, which form the cover, present the same stratigraphy (Algouti,1998; Lalaou et al.,1991; Michard,1976; Moret,1931; Pouit,1964) (Figure.1,2). The Permo-Triassic is formed by argilogressive and conglomeratic formations, showing fini-Triassic basaltic flows at the top. The Jurassic is present as a red formation attributed to the Dogger and a formation of dolomites and gypsum marls related to the Lias. The Infra-Cenomanian consists of sandstone conglomerates and marls. The Cenomano-Turonian, is represented by a bar, about $10 \mathrm{~m}$ thick, of finely sandstone limestone or flint dolomite towards the summit. It constitutes the level of manganese mineralization. Its upper part is karstified by the ante-Senonian emersion that occurred. A red argilo- sandstone formation constitutes the Senonian with gypsum with carbonate intercalations. It is the Ait Abbès dolomitic limestone and marl formation. It corresponds to an evaporitic series of Santonian age (Algouti,1998; Algouti,1999). The Paleocene and Eocene are represented by fossiliferous phosphate limestone's with Thersites, Nummulites and Alveolinids.

\subsection{Description of the units}

The section of Asfalou is $220 \mathrm{~m}$ thick and $180 \mathrm{~m}$ for that of Anmitar. They are formed of detrital material of red color (Figure.3 and 4). The two sections are subdivided into three units $\mathrm{U} 1, \mathrm{U} 2, \mathrm{U} 3$. The two units 2 and 3 generally show an evolution from a carbonate chemical pole towards a more and more thin detritic pole, it is represented at the base by a conglomeratic level translating the deposit in a more energetic environment (Anmitar section), followed by gypsiferous clays with intercalation of carbonate banks (dolomitized), for the Asfalou cut unit 3. The passage from carbonate deposits to channel sandstone deposits at the top shows an evolution from a medium to high hydrodynamic energy medium to a medium to high energy medium, as shown by the different sedimentary figures (channel filling, tangential oblique bedding, cross-bedding). The intercalations of carbonate bars reflect incursions with a marine regime marking a slight bathymetric increase in an intertidal zone affected by temporary emersions originating from the formation of fenestrae structures and desiccation slits. The mudstone texture, parallel and undulating laminations of algal origin are evidence of an environment with weak hydrodynamics. The stromatolithic facies are related to algal levels developed in an intertidal to supratidal domain.

\subsection{Sedimentary figures}

Oblique bedding: Most oblique-bedded beams are indicators of the direction and direction of flow. They are related to the lateral migration of sandy wrinkles. Wave wrinkle cross-laminate (="waveripplestrata"). There are two cases for oblique and crisscrossed beddings: Normal case (no displacement and deformation). The direction of transport will be either from the lover to the downstream (we measure the direction and direction of the sheets) for the oblique flat bedding or measured at the bottom of the surface in gutters for the crossed bedding. Case of displacement and deformation: the posterior deformations of deposit incline the bedding.

As in the first case, the direction and inclination of each oblique sheet are measured, then the direction and inclination of the beds, the whole is restored to its original (horizontal) position using the Wulf canvas in stereographic projection on the poles of the sheets (Durand,1978).

Channels: Studies for reconstructing the direction of paleocurrents in channels consist of measuring the channel axes' orientation.

Bioturbation: is defined as all the disturbances induced by the activity of organisms living on the surface (epibenthic) and in the superficial sediment (benthic) (Rhoads, 1974). 
Kerkoubs: (from the Arabic verb kerkab to ball). These are indurated concretions of variable size (5 to $10 \mathrm{~mm}$ ), more or less spherical, disseminated or grouped in given horizons within sandstones. The presence of kerkoubs indicates the warm and semiarid climate (Durand,1978). The presence of dissolution holes shows vadose diagenesis in an intertidal zone. Also, the presence of dissolution demonstrates the superior intertidal environment.

Ripples marks: result from the action of a unidirectional current, are found in all environments (river or sea) and at all depths. Asymmetrical ripples: the action of a unidirectional current creates these at relatively low speed.

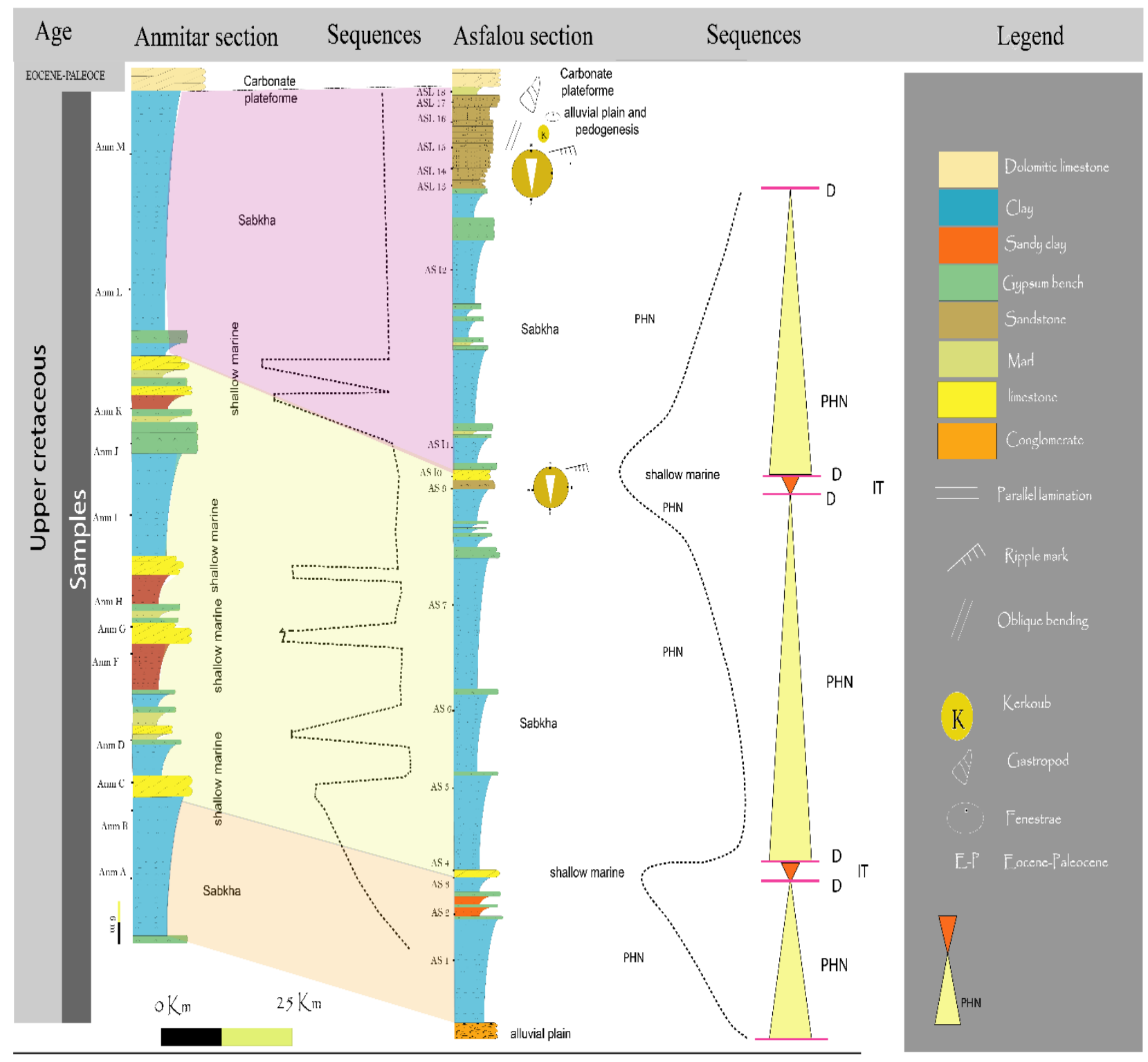

Figure.3: Lithostratigraphic column with vertical variation graph of the deposit environments, Anmitar section on the left side of the figure, Asfalou section on the right side of the figure. 


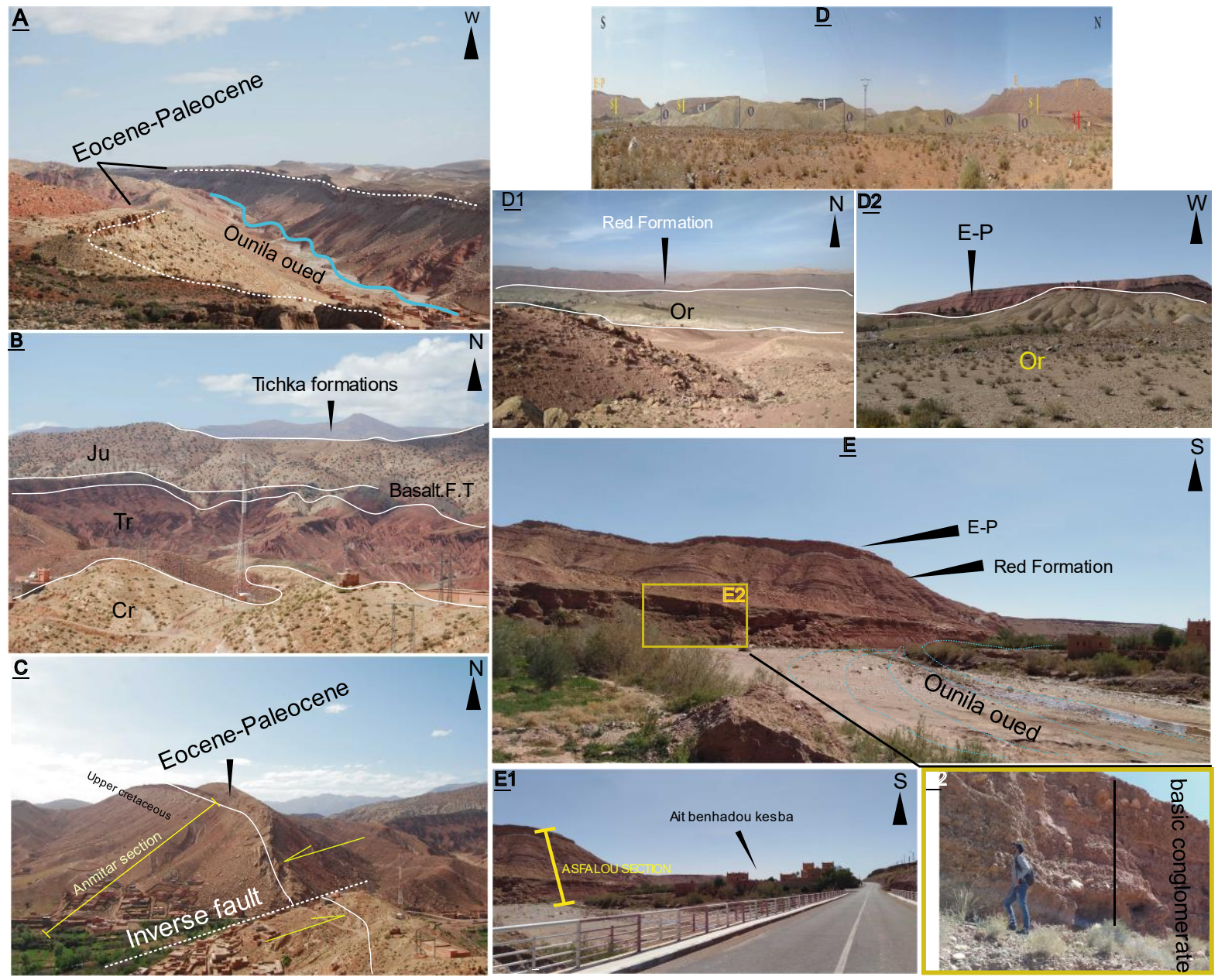

Figure 4: Plate showing the different facies and formations outcropping in the study area, A: Panoramic view showing the large Eocene-Paleocene formation, covering the entire red series, with the Ounila wadi separating the two sides: B : Panoramic view at the Anmitar level showing a stratigraphic succession of Cretaceous, Triassic and Jurassic with the presence of Triassic finite basalt, C: a large reverse fault that dislocates a carbonate bar from the (Eocen-Paleocene) into two offset parts, D: a marvellous stratigraphic succession that sets up some formations of study sectors, from left to right we have (Triassic, Ordovician, Senonian and Eocene-Paleocene), D1 and D2: some Eocene and Devonian details; E: the Asfalou section with gypeous bars, E1 and E2: details of some facies of the Asfalou section.

\subsection{Clay Analysis}

A study of the Senonian clays of the ANMITAR -ASFALOU basin provides more details on the palaeogeography of the study (Farah et al.,2021) (Figure.5). The relative abundance of illite and muscovite with small palygorskite percentages varies in the clayey parageneses. It represents 20 to $25 \%$ of the clay fraction in clayey-sandstone levels and sometimes kaolinite. In the limestone bars corresponding to the base of the units, palygorskite (50 to $75 \%$ of the clay stock) is always associated with sepiolite (Farah et al ,2021).) The increase in the relative abundance of illite and muscovite in the carbonate levels is probably due to sea level rises. The increase in the water slice leads to decreased detrital inputs and favours more chemical sedimentation in a relatively shallow basin. The increase in the magnesium content in the Figure 4: Plate showing the different facies and formations outcropping in the study area, A: Panoramic view showing the large Eocene-Paleocene formation, covering the entire red series, with the Ounila wadi separating the two sides: B: Panoramic view at the Anmitar level showing a stratigraphic succession of Cretaceous, Triassic and Jurassic with the presence of Triassic finite basalt, C: a large reverse fault that dislocates a carbonate bar from the (Eocen-Paleocene) into two offset parts, D: a marvellous stratigraphic succession that sets up some formations of study sectors, from left to right we have (Triassic, Ordovician, Senonian and Eocene-Paleocene), D1 and D2: some Eocene and Devonian details; E: the Asfalou section with gypeous bars, E1 and E2: details of some facies of the Asfalou section. 

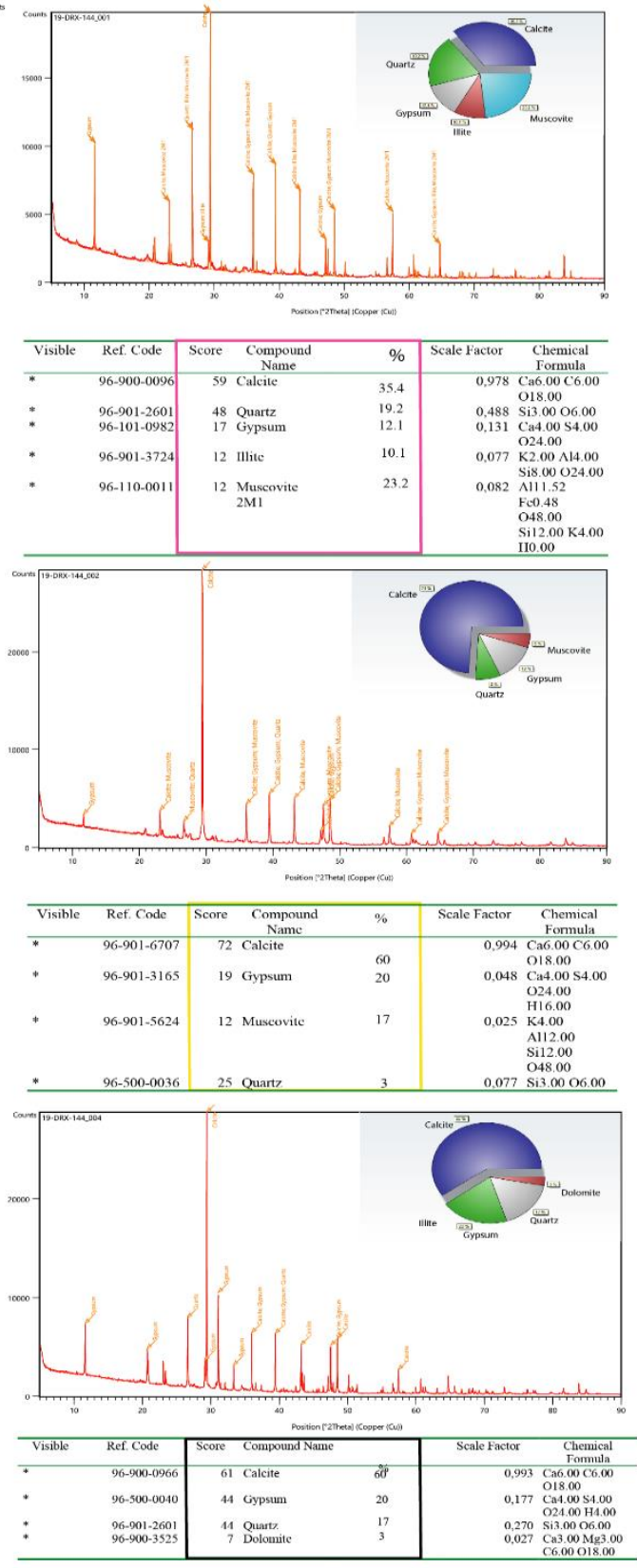
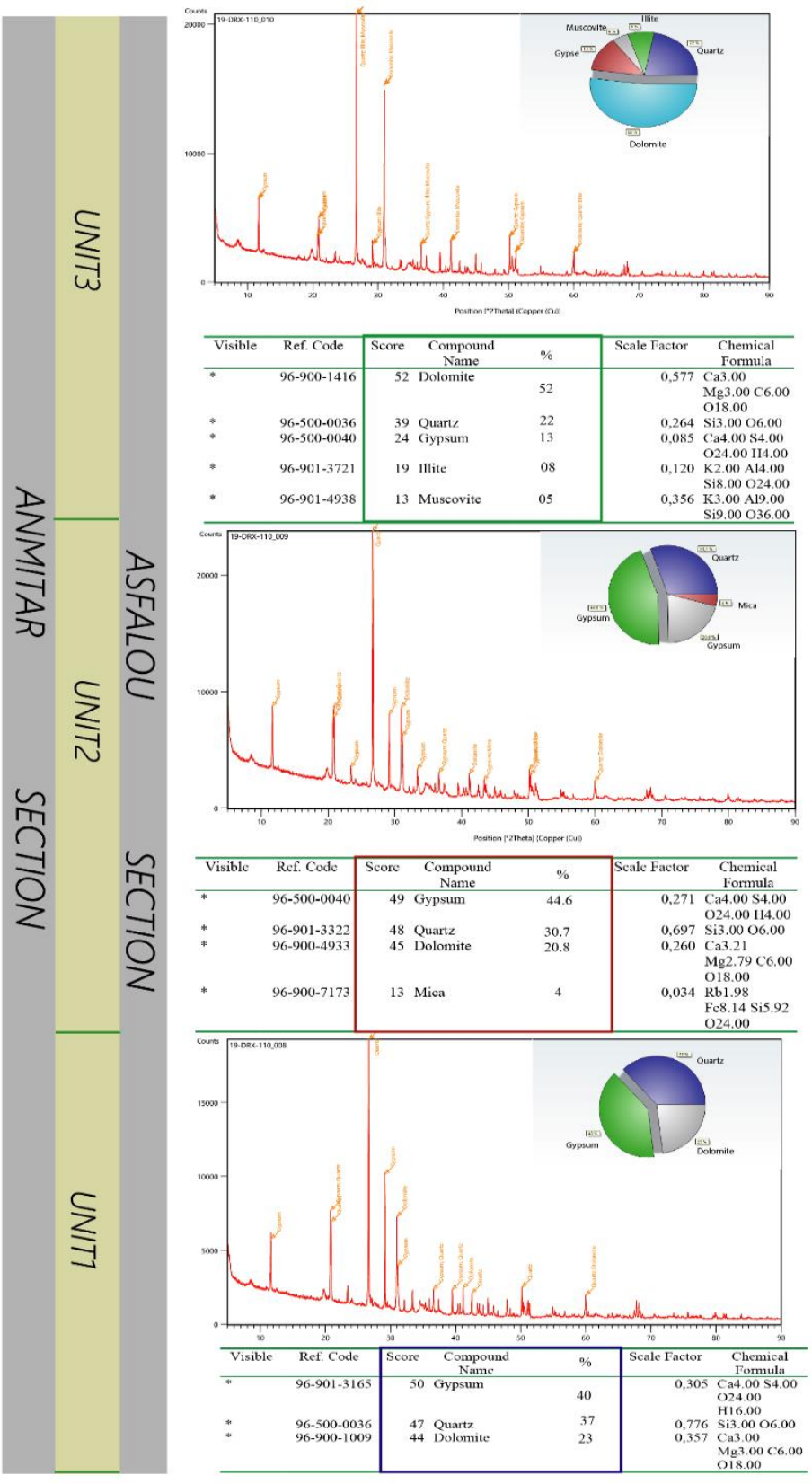

Figure.5 Vertical variations of clay and non-clay mineral compounds along the sections produced, on the left of the figure graphic representation of the variations of the minerals, indicated for the three units that make up the Anmitar section, on the left of the figure graphic representation of the variations of the minerals indicated for the three units that make up the Asfalou section.

\subsection{Exoscopy}

The exoscopic study of quartz grains shows, on the one hand, the existence of several types of mechanical and chemical erosion (Figure.6), and on the other hand, the presence of dissolution figures on the surface of several quartz grains, the quartz grains of Anmitar and Asfalou sections, they showed that these grains are transported by wind and water. These modes of transport are recognized by the presence of traces of crescent and V-shaped shocks on the surface of the grains, which then underwent an evolution in the shallow intertidal marine environment marked by the precipitation of silica resulting from the evaporation of water highly concentrated in silica and dissolution. 


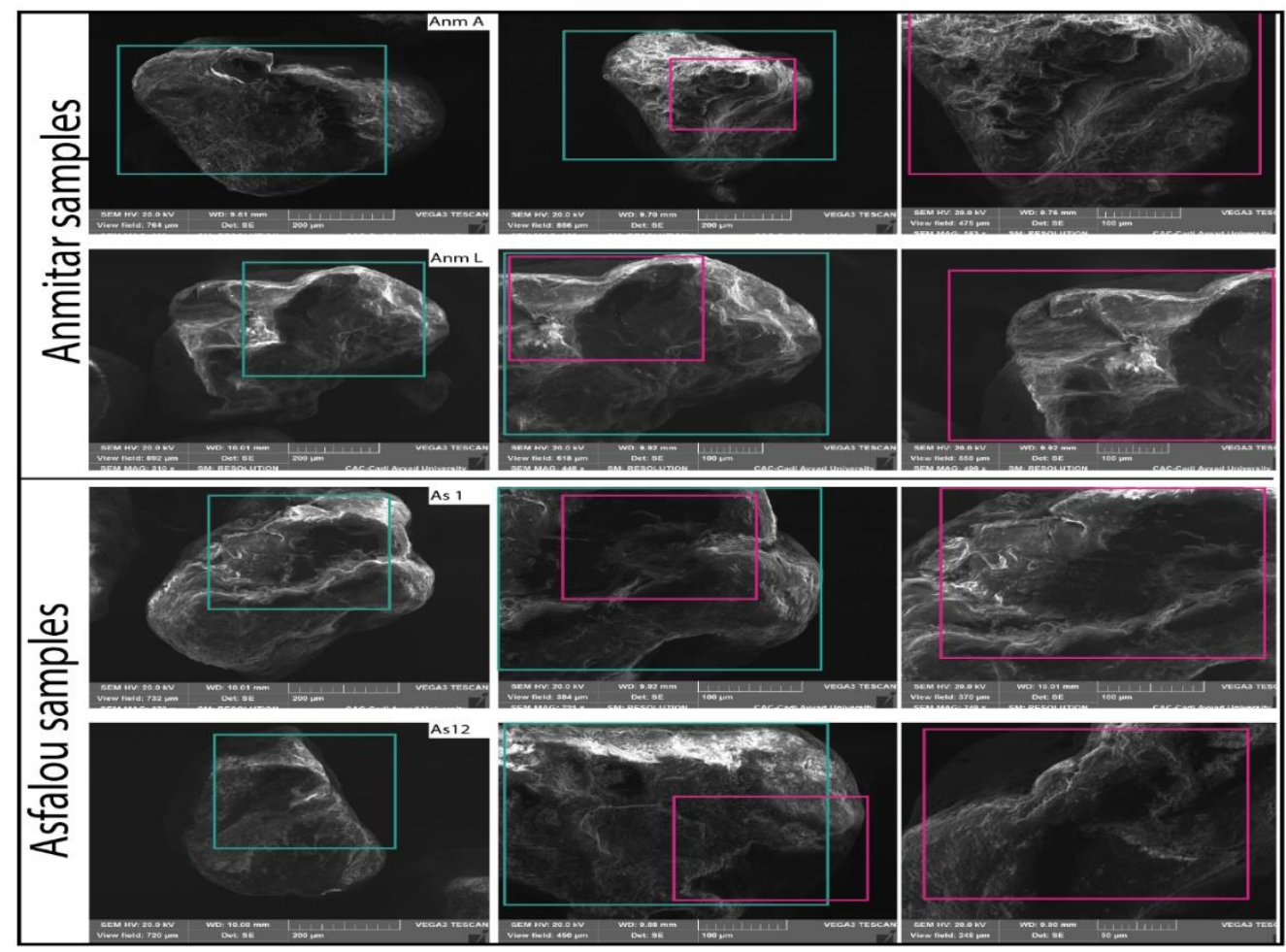

Figure. 6 The photos show a general view and a detailed view (different faces saved at the surface of quartz) of the grains of the quartz from the samples taken from the section of Asfalou and Anmitar.

\subsection{Paleogeographic evolution}

In the Upper Cretaceous, the paleogeographic evolution is notably marked by the closure of the western part of the Tethys, by the continued opening of the North Atlantic, and by the South Atlantic's rapid opening. In addition, it is generally accepted that the Upper Cretaceous is a period of warm climatic optimum. Globally, this results in a transgressive context whose translation is a maximum marine extension (Baron et al.,1996 ; Frakes et al., 1994) (Figure.7)

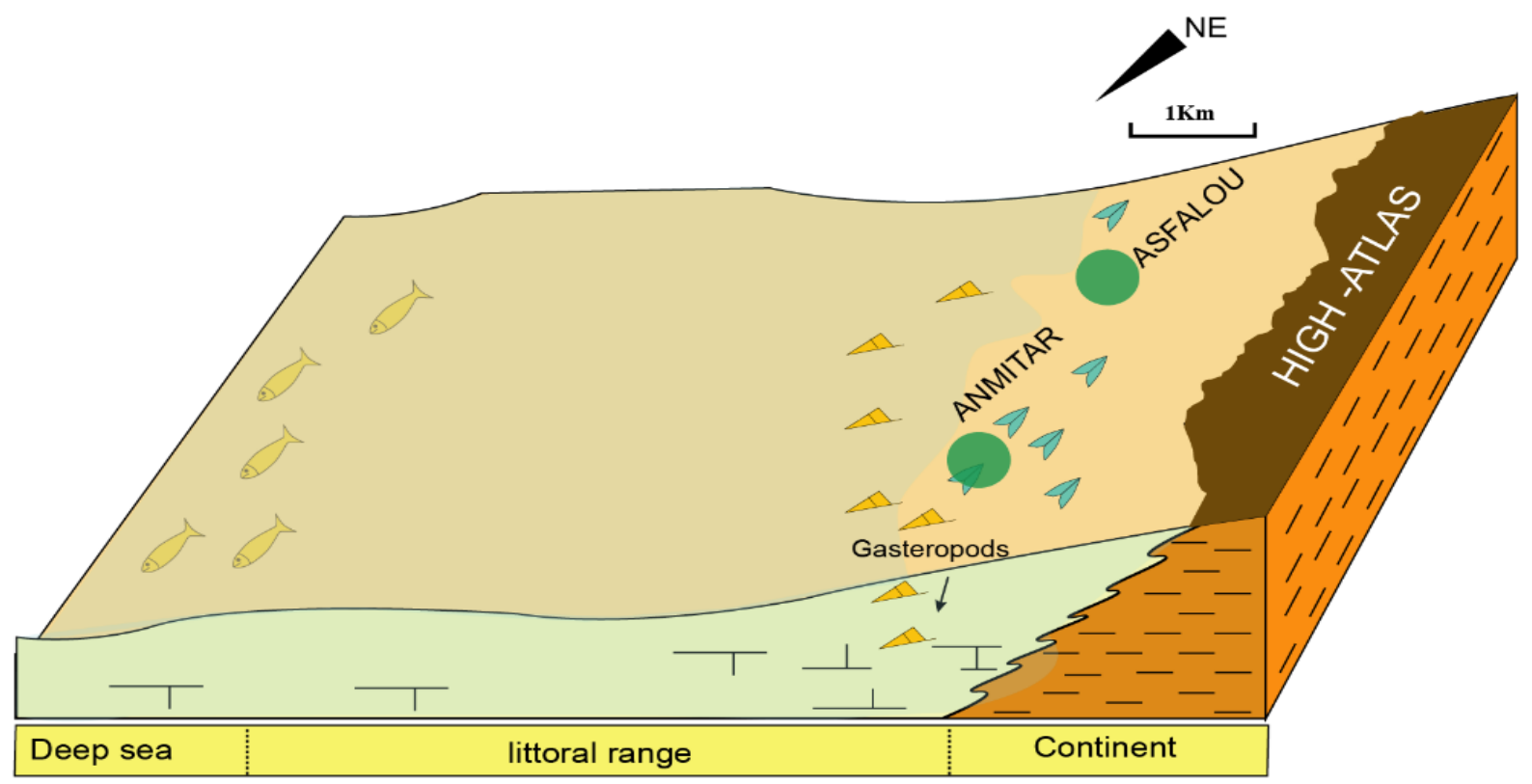

Figure.7 A simplified model for the deposit of Senonian formations in the study area. 


\section{Conclusion}

The Senonian is a monotonous set of clayey pink and red sands, with secondary gypsum beds. These lagoon formations are 110 $\mathrm{m}$ to $150 \mathrm{~m}$ thick in the Asfalou -Imini and Anmitar region. From a tectonic point of view, the Cenomanoturonian limestones were deposited during a relatively calm period. In contrast, the Senonian was a period of tectonic activity that resulted in the reactivation of the subsidence of the basin and the return to detrital sedimentation, related to the overall uplift of this area already subject to erosion. The sedimentation of the limestone and dolomitic marl formation is marked by evaporitic levels in the form of banks of impure gypsum "saccharoid", of primary or fibrous gypsum of secondary origin. The presence of this type of sedimentation characterizes a laguno-continental environment. Therefore, this formation's deposits result from sedimentation in a calm, shallow and confined environment, subject to phases of emergence with salinity variations under a hot and arid climate. The clay analyses and exoscopy confirmed, that the deposition of the red formation of senonian series with its limestone intercalations was carried out in a continental-lagoon environment.

\section{Acknowledgments}

The authors are very grateful to the anonymous reviewers for their valuable comments and suggestions and to the journal editor for a careful review of the article, which helped present work lucidly.

\section{References}

[1] ALGOUTI, A. (1998). Etude stratigraphique et sedimentologique du Lias de la region de Telouet, Haut Atlas. Cadi Ayyad University.

[2] ALGOUTI, AHMED. (1999). Le Sénonien (Coniacien, Santonien, Campanien et Maastrichtien) du HautAtlas occidental (Maroc): sédimentologie, stratigraphie séquentielle, biostratigraphie et évolution géodynamique.

[3] BARON-SZABO R. C. \& STEUBER T. (1996) - Korallen und rudisten aus dem Apt im terti iren Flysch des Parnass-Gebirges bei DelphiArachowa (Mittelgriechenland). Berliner geowissenschaftliche Abhandlungen, E 18: 3-75.

[4] DURAND, M. (1978). Paleocurrents et reconstitution paléogéographique. L'exemple du Buntsandstein des Vosges méridionales (Trias inférieur et moyen continental).

[5] ETTAKI, M., SADKI, D., CHELLAÏ, E. H., \& MILHI, A. (2008). Interaction eustatisme-tectonique dans le contrôle de la sédimentation au Jurassique inférieur et moyen dans la région de Todrha-Dadès (versant sud du Haut-Atlas central, Maroc). Notes Mémoires Serv. Géol. Maroc, 527, 55-64.

[6] FARAH, A., ALGOUTI, A., \& ALGOUTI, A. (2021). Sediment logical and Lithostratigraphic Study of the Senonian Series in Timstiguite Region, Central High Atals, Morocco. Journal of Environmental and Agricultural Studies, 2(1), 01-11.

[7] FARAH, A., ALGOUTI, A., ALGOUTI, A., HADACH, F., \& MOURABIT, Z. (2021), March) Sedimentological and lithostratigraphic study of the Foum El Kous Senonian, Central High Atlas of Morocco. In E3S Web of Conferences (Vol. 240, p. 04001). EDP Sciences.

[8] FRAKES, L. A., \& JIANZHONG, S. (1994). A carbon isotope record of the upper Chinese loess sequence: Estimates of plant types during stadials and interstadials. Palaeogeography, Palaeoclimatology, Palaeoecology, 108(1-2), 183-189.

[9] FRIZON DE LAMOTTE, D., ZIZ, M., MISSENARD,Y., HAFID, M., EL AZZOUZI, M., MAURY, R. C., CHARRIERE, A., TAKI, Z., BENAMMI, M., MICHARD, A., (2008). The Atlas system. Lecture Notes in Earth Sciences 116, 133-202.

[10] FRIZON DE LAMOTTE, D., LETURMY, P., MISSENARD, Y., KHOMSY, S., TUIZ, G., SADDIQI, O., GUILLOCHEAU, F., MICHARD, A., (2009). Mesozoic and Cenozoic vertical movements in the Atlas system (Algeria, Morocco, Tunisia): an overview. Tectonophysics 475: 9-28.

[11] GIESE, P., JACOBSAGEN, V.,(1992). Inversion tectonics of intra-continental ranges: High and Middle Atlas, Morocco. Geologische Rundschau 81: 249-259.

[12] LALAOUI, M.-D., BEAUCHAMP, J., \& SAGON, J.-P. (1991). Le gisement de manganèse de I'Imini (Maroc): Un dépôt sédimentaire sur la ligne de rivage; The Imini Mn-Ore deposit (Morocco): A sedimentary shoreline deposit. Chronique de la recherche minière, (502), 14-23

[13] LAVILLE, E., PIQUÉ, A., (1992). Jurassic penetrative deformation and Cenozoic uplift in the Central High Atlas (Morocco) : A tectonic model. Structural and orogenic inversions. Geologische Rundschau $81: 157-170$.

[14] MARCELINO, V., MUSSCHE, G., \& STOOPS, G. (1999). Surface morphology of quartz grains from tropical soils and its significance for assessing soil weathering. European journal of soil science, 50(1), 1-8.

[15] MATTAUER, M., TAPPONIER, P., PROUST, F., (1977). Sur le meanismes de formation des chaines intracontinentales. L'exemple des chaines atlasiques du Maroc. Bulletin de la Société Geologique de France 77 : 521-526.

[16] PIQUE, A., \& MICHARD, A. (1981). Les zones structurales du Maroc hercynien. Sciences Géologiques, bulletins et mémoires, 34(2), 135-146.

[17] MORET, L. (1931). Recherches géologiques dans l'Atlas de Marrakech. Protectorat de la République française au Maroc Direction générale des travaux publics Service des mines et de la carte géologique.

[18] POUIT, G. (1964). Les gîtes de manganèse marocains encaissés dans les formations carbonatées: éléments pour une synthèse. Chronique des Mines et de la Recherche minière, 32(336), 13-331.

[19] RHOADS, D. C., \& DC, R. (1974). Organism-sediment relations on the muddy sea floor. 